\title{
SYMBOLS OF STATEHOOD: MILITARY INDUSTRIALIZATION AND PUBLIC DISCOURSE IN INDIA
}

\author{
David Kinsella \\ School of International Service \\ American University \\ kinsell@american.edu \\ Jugdep S. Chima \\ Department of Political Science \\ University of Missouri-Columbia \\ c619913@ showme.missouri.edu
}

Presented at the annual meeting of the International Studies Association - Midwest Region, 3-5

October 1997, Cleveland. Our thanks to Timothy Birch and Kelly Shaw for research assistance. 


\title{
SYMBOLS OF STATEHOOD: MILITARY INDUSTRIALIZATION AND PUBLIC DISCOURSE IN INDIA
}

\begin{abstract}
This paper examines the forces driving the pursuit of military production capacity in India, including those behind the Indian nuclear and space programs. We are mainly interested in whether symbolic motivations regularly find expression in the public discourse. We review all articles on the subject of weapons development and production appearing in India Today from May 1977 through December 1996. There are three closely interrelated yet distinguishable concerns in the public discourse which we consider symbolic: that military industrialization is a means of asserting India's autonomy in international affairs, that is is a means of establishing India's international status and prestige, and that it serves to enhance India's self-image. We contend that the symbolic motivations represent a systematic component of the military industrialization process in India. The precise form that symbolic motivations take vary - some statements seem to have more symbolic content than others — but, as a whole, such references are not rare or isolated.
\end{abstract}




\section{SYMBOLS OF STATEHOOD: MILITARY INDUSTRIALIZATION AND PUBLIC DISCOURSE IN INDIA}

Each sees the other do the same as it does; each does itself what it demands of the other, and therefore also does what it does only in so far as the other does the same.... They recognize themselves as mutually recognizing one another.

- Hegel

I am a totally indigenous product. I have never studied or worked abroad.

- Kota Harinarayana

Light Combat Aircraft project

Symbols are an important feature of social interaction. Things we say, things we do, things we possess often have symbolic meaning for ourselves and for those with whom we come in contact. Similarly for states and international interaction: there are certain national characteristics and forms of state behavior which seem to be infused with a good deal of symbolic significance. Possession of advanced military capability is perhaps the most obvious example. Symbols, particularly those that contribute to a state's status and prestige, are widely acknowledged to motivate state behavior. But schools of thought in international relations theory differ on what drives the very quest for status and prestige, and the ends, if any, to which such symbolic capital is directed.

Disputes about the role of symbols in international relations are sometimes quite subtle, but also quite heated at the theoretical level. General disagreements between realists and social constructivists regarding the content of utility functions, the process of identity construction, and, ultimately, social ontology will not soon be resolved and will therefore continue to define the battle lines separating these schools of thought. It would be nice if we could construct a series of empirical tests which might settle some of these issues, at least as regards symbolism, but to date this has not been undertaken.

Moreover, any such task is immensely complicated by the fact that "competing" schools of thought are not, strictly speaking, congruent in the sense of offering alternative explanations of the same things. Realists, for instance, treat status and prestige as part and parcel of state interests defined in terms of power, the assumed driving force behind foreign policy. Constructivists treat these as elements of state identity, something to be explained.

One could fashion a multi-stage causal model which took into account, first, factors affecting state identity and preferences and, second, the impact of those preferences on state behavior. In principle, this would allow for the evaluation of the relative merits of both realist and constructivist arguments within the context of a single empirical model. ${ }^{1}$ Unfortunately, reliable empirical indicators of symbolic

1. This tack would not, of course, sit well with the post-positivists within the constructivist school. See Lapid 1996 and Yee 1996. 
motivating forces such as status and prestige do not seem to have captured the imagination of those engaged in rigorous qualitative or quantitative measurement and analysis. That is an exceedingly difficult enterprise in any event. We are, after all, alluding to matters of cognition, and abandonment of the state as unit of analysis - the unit favored by realists and constructivists alike — is probably a minimum requirement for empirical analysis faithful to some of the finer points of theoretical dispute.

Relocating to a lower level of analysis, where we might scrutinize statements by policymakers for evidence of symbolic motivations for their actions, does not get us in the clear, however, if it is militaryrelated behavior we want to explain. As Suchman and Eyre point out, "military procurement reflects an essentially ritualistic belief in modern weaponry as a distinguishing emblem of the modern nations; unfortunately, since rational military planning is another such emblem..., these nonrational motives are unlikely to receive formal acknowledgment." ${ }^{\text {2 }}$ Suchmand and Eyre are skeptical that policymakers will actually admit to being motivated by such things as status and prestige. Therefore, they suggest proceeding directly to an empirical examination of the state's participation in international organizations and other institutional forms, since these are the repositories of world-level cultural practices which purportedly constitute state preferences and identity. ${ }^{3}$

Although we are mindful of the potential bias against overt expression of symbolic, "nonrational" motivations for military-related behavior, we think it premature to disregard public discourse merely on the basis of these suspicions. Thus we have set a very simple empirical task for ourselves in this paper. We examine the rationales given for the pursuit of indigenous military production in India, including those behind the Indian nuclear and space programs. We are particularly interested in whether symbolic motivations, such as international status and prestige, regularly find expression in the public discourse, so we concentrate our discussion on these sorts of rationales. But other motivations "rational," "instrumental," "material" ones — are plainly evident in the materials we examine, so we can also give some indication of the relative prominence of symbolic motivations. To accomplish our task, we have systematically reviewed all articles on the subject of weapons development and production appearing in India Today, a popular news weekly, from May 1977 through December 1996. We assume that articles in India Today are representative of public discourse in India. They reflect the views of the media, as well as the views of government officials and defense intellectuals as reported in the media. As one expects from a news weekly, they are written for popular consumption and probably cater somewhat to the tastes of the readership. In short, the material we have reviewed has had a role in shaping, and was shaped by, Indian public discourse on military industrialization.

Before presenting our findings, we want to do two things. First, we provide a brief overview of the evolution of military production capacity in India. Second, we examine select schools of thought in international relations theory for which an empirical treatment of the symbolic motivations for Indian behavior may be relevant: realism, social constructivism, and theories of strategic culture, including postmodern contributions. We should like to emphasize, however, that we do not intend to evaluate the relative merits of these "competing" schools in the context of our empirical data. Although

2. Suchman and Eyre 1992, 151.

3. See also Eyre and Suchman 1996. 
international relations theory has something to say about the role of symbols in the complex of forces driving state behavior, ours is primarily an exercise in descriptive inference, not causal inference. By descriptive inference, we mean "the process of understanding an unobserved phenomenon on the basis of a set of observation." ${ }^{\prime 4}$ At this stage we are not prepared to systematically examine causal mechanisms, either those which account for Indian military industrialization or those behind the symbolic motivations themselves. It is here that the theoretical traditions in international relations may differ, and the settling of such matters is beyond the reach of both our data and analysis. The intent of this paper is to evaluate a straightforward "descriptive hypothesis": that symbolic forces driving military industrialization in India exist, and that they find systematic expression in the public discourse.

\section{Military Industrialization in India}

The Indian state inherited much from its former colonial master, including several ordnance factories and an aircraft factory. During the period immediately after independence, domestic production was limited primarily to small arms and ordnance. Britain was also the source of most of India's weapons imports during that time. British weaponry was generally familiar to the Indian armed forces, and the new state was in no hurry to become entangled in the cold war by acquiring American or Soviet equipment. By the mid-1950s, after Pakistan signed a military aid agreement with the United States and subsequently joined both the Southeast Asian Treaty Organization and the Baghdad Pact, India had a new set of security incentives for both increased weapons imports and the development of an indigenous defense industry. These would be reinforced by the frequently high levels of tension on the subcontinent, including a war with China and two more with Pakistan, and the continuing flow of advanced weaponry to the region.

\section{What India Builds}

Hindustan Aircraft Ltd. began licensed production of the British Gnat fighter in 1961. It later developed and produced an advanced version, the Ajeet, but with only limited success. When HAL signed the licensing agreement to produce the Gnat in 1956, it also commenced development of its own supersonic fighter, the HF-24 Marut. ${ }^{5}$ The first planes entered service in 1964, but the project ultimately foundered on the inability to either produce or import an appropriate jet engine. Production ceased in 1975. Prior to the Sino-Indian war, India had been looking to the Soviet Union as a source of advanced weaponry. In 1962, after the United States agreed to sell Pakistan F-104 Starfighters, to be the most advanced in the region at the time, India signed an agreement with the Soviets for the

4. King, Keohane, and Verba 1994, 55; see, more generally, 34-74.

5. This is section draws freely from several good analyses of India's defense industrial capacity: Smith 1994, Hoyt 1996, Thomas 1986, Wulf 1986, Sanders 1990, Graham 1984, Nolan 1991, and Office of Technology Assessment 1991. 
delivery and then production of MiG-21 fighters. HAL began producing the aircraft in the aftermath of the 1965 war with Pakistan and increasingly indigenized versions were manufactured throughout the 1980s. ${ }^{6}$

A deal to purchase Soviet MiG-29 Fulcrums was announced in 1984 and, after some haggling over the precise version to be delivered, the planes began arriving in 1987. The deal apparently also included a contract for licensed production, but HAL-produced Fulcrums have not yet materialized. Considerable effort is being devoted to India's own Light Combat Aircraft project, a collaborative effort by HAL and the government's Defense Research and Development Organization to design and produce an indigenous fighter catered to the needs of the Indian Air Force. Although the project has captured the imagination of those extolling the virtues of Indian self-sufficiency in military production, HAL has had to resort to foreign technical assistance and imported components for LCA prototypes. General Electric, for instance, has supplied engines to buy time for the development of the indigenous GTX-35 engine. The LCA will probably make its appearance around 2000, with performance characteristics comparable to the American F-16.

Vickers of Britain licensed the production of its Mk.3 main battle tank in 1961, and Avadi Tank Works began production of the tank, renamed Vijayanta, in 1965 . $^{7}$ Dissatisfaction with the Vijayanta prompted planning for the development of an indigenous MBT, ultimately dubbed the Arjun, to be overseen by DRDO's Combat Vehicle Development Establishment. Revised design specifications have led to delays, the most serious of which relate to engine development. German engines will power initial versions, which may also rely on German transmissions, tracks, and fire control systems. Since 1983, the Indian Army has been supplied with Soviet T-72 tanks while awaiting the Arjun. Avadi was granted a production license for the T-72 in 1980, but the Indian version did not enter service until 1988. Still, this project has drawn much praise, with some even suggesting that the local content of the Indian T-72 exceeds that of the Arjun. ${ }^{8}$

India's regional aspirations have also prompted defense industrial activities in support of a significant naval presence in the Indian Ocean. The expense involved in shipbuilding prevented domestic production of anything other than minor vessels until the mid-1960s. At that time, after the Indian government acquired Mazagon Docks Ltd. and the Garden Reach Workshop Ltd., Britain licensed production of the Leander Class frigate. This experience facilitated the development of an improved Indian version, the Godavari Class, the first of which was completed at Mazagon in 1983. It too integrated a number of imported components, including Soviet weaponry and Western electronics. In 1987, the Type 15 Destroyer Program was announced, and the first vessel, the Delhi, was launched in 1991. The ship does rely on some foreign components, but also features Indian electronics, sonar,

6. HAL has also produced the British version of the Anglo-French Jaguar fighter and Soviet MiG$27 \mathrm{~s}$.

7. Hoyt $(1996,102)$ points out that many mistakenly refer to the Vijayanta as an Indian version of the British Chieftain, probably because the two tanks use the same engine. The Mk. 3 was rejected by the British Army and was produced by Vickers only for export.

8. Ibid., 126. India also produces the Soviet BMP-2 infantry combat vehicle, renamed the Surath. 
and missile systems. India is producing the Russian Tarantul I Class corvette under license as well as another corvette, the Khukri Class, which is the first Indian designed and built warship. Submarine production began as part of a 1981 deal with Germany for the purchase and then assembly of Type209 diesel-powered attack submarines. The first Indian built boat was commissioned in 1991 and a second in 1994. The project encountered time delays, cost overruns, and technical problems. New construction was terminated in 1988. ${ }^{9}$ The Indian Navy leased a nuclear submarine, a Charlie I Class, from the Soviets in 1988. The deal probably reflected some ambition to eventually produce an Indian nuclear submarine. There have been reports of explorations into the viability of such an endeavor, but the immensity of such a project and the Navy's rather sour experience with the Soviet vessel suggests that nuclear submarine production is probably not high on the list of priorities. Production of an aircraft carrier has also been explored, but set aside for similar reasons. ${ }^{10}$

Development and production of missile systems is a direct outgrowth of the closely watched Indian space program. India's first satellite, the Aryabhata, was launched by a Soviet rocket in 1975, with subsequent launches in 1979 (Bhaskara I) and 1981 (Bhaskara II). The indigenous Space Launch Vehicle program achieved its crowning success in 1980 with the launch of the four-stage SLV-3 rocket which orbited a 35-kg Rohini satellite. India thus became the seventh nation to place a satellite in space with an indigenous rocket. The Indian Space Research Organization and DRDO teamed up in the early 1980s to establish the Integrated Guided Missile Development program to promote indigenous development and design missile systems. By the mid-1980s, the Trishul surface-to-air missile was tested. This was followed, in 1988, by the test launch of the high-profile Prithvi surface-to-surface missile with an indigenous inertial guidance system and the capability of delivering a nuclear payload up to 150 miles. The Agni intermediate-range ballistic missile was tested in 1989 and again in 1992. Its range is said to be over 1500 miles and its payload of up to 2.5 tons is sufficient to carry conventional, chemical, or nuclear warheads. ${ }^{11}$

The space program, and especially the IGMD program, take on added significance in light of India's demonstrated nuclear capability. The nuclear program began shortly after independence with the establishment of the Atomic Energy Commission (subsequently, the Department of Atomic Energy). India's first research reactor became operational in 1956, and that same year a deal was signed with Canada for assistance in the construction of the Rajasthan Atomic Power Plant around two Canadian designed heavy water reactors (RAPP-I and RAPP-II). This plant ultimately provided the plutonium used for the 1974 Pokhran nuclear test. Now India operates several nuclear reactors, including a few fast breeder reactors. The nuclear program has often encountered snags, as when Canada terminated technical assistance in the aftermath of the nuclear explosion, but the government remains committed to

9. The reason given by the Rajiv Gandhi government for the cancellation was actually Germany's dealings with South Africa, in particular, the sharing of information regarding performance characteristics of the Indian submarine. See Smith 1994, 154.

10. See Hoyt 1996, 155-157.

11. The Akash medium-range SAM and the Nag third-generation anti-tank missile are other accomplishments of the IGMD program. 
the program. India has always asserted that its nuclear program targets peaceful uses of nuclear energy; but on matters of principle, it has refused to sign the 1968 nuclear Non-Proliferation Treaty (and, of course, the 1995 NPT extension). Given the concerted effort devoted to missile development, particularly the Agni IRBM, it is clear that India is seriously exploring the possibility of deploying its own nuclear missile force.

\section{Why India Builds}

Observers of military industrialization in the third world typically highlight the "rational" or "instrumental" ends toward which indigenous arms production is directed. States acquire arms in order to improve their immediate security vis-à-vis rival states. Domestically produced arms have the added benefit of guarding against the manipulation of weapons supplies, including spare parts, which might otherwise be undertaken by foreign suppliers with their own policy objectives. Domestic arms production has also been given an explicitly economic rationale. States obviously need not purchase from abroad what they build themselves, so arms production is viewed as means of conserving foreign exchange. Military industrialization may be pursued for purposes of technological development and spin-off to the civilian sector of the economy. In addition to these commonly cited motivations for military industrialization, we argue that there are also more "symbolic" motivations.

The most obvious impetus behind Indian weapons production is provided by the country's immediate security environment, especially its strategic relationships with Pakistan and China. Territorial disputes over the Kashmir with Pakistan and along the Himalayan border with China are complicated further by religious and ideological differences. Throughout the period of Indian independence these have generated high levels of hostility and several overt military conflicts. Even when relations with Pakistan and China are relatively quiescent, India has remained attentive to these states' arms acquisitions: what they import, what they produce, what they try to produce. Levels of regional hostility and levels of regional armament explain, in large part, why India has acquired advanced weaponry for its armed forces.

While India's immediate security needs have been interpreted as requiring a well-armed defense forces, on strictly military grounds there should be no reason to prefer domestically produced weaponry over imports, assuming comparable performance characteristics. But there are reasons both to prefer and not to prefer domestic production on economic grounds. In his extensive and balanced study of Indian security policy, Thomas has noted that a policy of indigenous weapons production "would mean a substantial increase in the scientific and technological knowledge of the country with attendant benefits for the civilian sector as well."12 To be sure, the pursuit of "military-led industrialization" is recognized far more explicitly in the academic literature than it is acknowledged by Indian statesmen. Production of killing machines would seem to demand something other than an economic rationale, especially in a democracy like India. Still, many analysts do agree that part of what drives military industrialization in

12. Thomas 1986, 249. Such views were put forth, but not always defended, in early studies of third world military production by Kennedy 1974 and Benoit 1973. 
India and elsewhere in the third world is the belief that arms production will promote development in adjacent sectors of the national economy. Of course, state leaders may be wrong — and much of the literature endeavors to show them the errors of their ways - but " $t$ the skepticism of academics in industrialized countries notwithstanding, the belief remains widespread that such programs can provide tangible economic and technological benefits as well as enhanced military security."13

Indigenous weapons production in India has also sometimes been justified as a means of conserving foreign exchange that would otherwise go to foreign purchases, but in almost all cases the policy of import substitution has failed to measure up to expectations. The problem is not unique to India. Scarce resources and the inability of third world armed forces to absorb large quantities of domestically produced weapons makes for very high unit costs, in which case importing weapons of even superior quality can be the cheaper alternative. Thomas has found that licensed production has been increasingly favored in India, especially by economic planners. They recognize "the need to strike an optimum balance between the cost and quality of weaponry; this is best obtained in the long run through both external technological transfers and domestic production."14 Here too there are costs, since licensing involves both the importation of parts and machinery as well as the payment of royalties. Still, the hope is that this paves a way for indigenization, one in the end less costly than attempts to indigenize cold turkey.

There are other reasons why India builds weapons, not unrelated to its security environment or industrial development. According to Katz, "[t]he most important factor driving LDCs to produce arms can be summarized quite easily: autonomy, that is, freedom of action in the domestic and international spheres." ${ }^{15}$ Actual or potential threats to national security are exacerbated when states find themselves dependent on others for defense. India, having experienced arms embargoes (e.g., those imposed by the United States during the 1965 and 1971 conflicts with Pakistan), bristles at the thought of lasting arms dependence. As Indira Gandhi put it, "We want India to be self-reliant and to strengthen its independence so that it cannot be pressurized by anybody...." In Indian independence in defense policy is enhanced by an indigenous arms production capacity, particularly the capacity to initiate or expand production in a pinch, as well as the capacity to maintain existing systems.

According to the Ministry of Defence, "Modernization of arms and equipment and a maximum degree of self-reliance and self-sufficiency in the shortest possible time have been the major objectives in our defence production effort.... No free nation... can afford to ignore the imperative need to

13. Conca 1992, 143; see also Kolodziej 1985, 53-54. Thomas concludes that "the growth of Indian military capabilities is, to a certain extent, unrelated to Indian threat perceptions and tends to be an autonomous trend based on civilian technological growth." See Thomas 1986, 291. See also Ball 1988 for a thoroughgoing critique of the view that the military — its manpower, organization, production priorities, etc. — constitutes an efficient means by which to promote economic development in the third world.

14. See Thomas 1986, 246-247, 251-252; also Smith 1994, Hoyt 1996.

15. Katz 1984, 4-5.

16. Tharoor $1982,88$. 
maintain constant preparedness to defend [against] any threat to its borders."17 Self- sufficiency in weapons procurement has taken on a degree of significance beyond diminishing the impact of arms embargoes during wartime; it has become an integral feature of India's stated policy of nonalignment. Principles of nonalignment have been adhered to more rigidly at some times and not others - Indira Gandhi's foreign policy vis-à-vis the Soviet Union falling into the latter category. But the desire to remain aloof from the cold war competition which entangled so many other third world states was the closest thing to an Indian strategic doctrine. ${ }^{18}$ With the cold war over, the policy of nonalignment has less resonance, but self-sufficiency in arms production, and independence more generally, still have claims on the Indian imagination.

Beyond immediate security imperatives and industrial development, the possession of indigenous weapons production capacity has taken on symbolic importance for India. Foreign policy under Indira Gandhi has received much attention on this score, and the Pokhran nuclear test epitomized India's quest for international recognition. In the opinion of one of Gandhi's biographers, Pokhran "was no more than a gesture of independence and a bid for inexpensive prestige." ${ }^{\prime \prime}$ William Barnds, long-time observer of India's role in world affairs, detected the symbolic motivations behind India's nuclear program well before the nuclear explosion occurred: "With each of the first Chinese test explosions there was a new demand by some Indians that their country produce similar weapons. The demands often seemed as much concerned with Indian prestige as with security." He adds that "The call for an Indian nuclear force also reflected a mood that the country should depend more on itself and less on outsiders." 20 Sisir Gupta, an Indian diplomat and academic, in 1965 referred to India as the "sixth Power in a world where only five are recognized to be great" and suggested that India could "either enter the club by defying the world and making a bomb or see to it that the bomb as a status symbol loses its significance because of effective progress towards disarmament." He was skeptical regarding

17. Quoted in Hoyt 1996, 69; our italics. See also Rao 1984.

18. Tharoor notes that Gandhi felt that "the Soviet Union had actively aided the enhancement of Indian self-reliance and therefore 'independence.' She appeared to believe that by offering industrial and technical knowhow to India, the Soviet Union was helping alleviate Indian dependence on the West." In her word, "the Soviet Union has not, during so many years of friendship, ever put pressure on us or told us what to do." See Tharoor 1982, 68.

19. Mansingh 1984, 59. See also Thankur 1994, 101, 106-107; Smith 1994, 187, 189.

20. Barnds 1972, 220-221. Smith suggests that Nehru too "recognized how much political power was commensurate with nuclear weapons," despite a great deal of ambivalence about India's pursuing a nuclear option. See Smith 1994, 179-180. The timing of the nuclear explosion has also been linked to Indian domestic politics - i.e., it rallied public opinion just when there were sign of discontent with Gandhi domestic economic policies. Indeed, domestic approval of the nuclear test was overwhelming and the belief was widespread that India's international prestige had been enhanced. See Smith 1994, 186; Brands 1990, 149; Thomas 1986, 45-46. 
the latter option because "military capability remains the most important source of a country's status, prestige and power...." 1

In addition to enhancing India in the eyes of the international community, domestic weapons production seems to have been partly motivated by the desire to enhance India in the eyes of Indians themselves. Again, this is a recurrent theme in defence policy under Indira Gandhi. One concern has been with the scientific and industrial community. In a 1968 interview, Gandhi lamented that "our intellectuals, our industrialists and businessmen do not yet feel proud of being Indians." ${ }^{22}$ She would later justify the Pokhran test by the need "for our scientists to know what they are capable of." 23 In 1992, Prime Minister Rao referred to the successful launch of the augmented SLV (after several failures) as "a morale booster for the scientific community." 24 The preoccupation with self-image has been extended to the whole of India as a nation. Without mentioning any specific weapons programs, Gandhi once commented that "while we must have arms to defend our country from any aggression, these arms, this military strength must be backed by conviction in our ideals and confidence in ourselves." ${ }^{25}$ Commensurate with India's policy of nonalignment, she also wished for an Indian identity unmolested by cold war politics: "we wanted [India] to be able to grow in its own way - to choose its own direction, to choose its own personality." 26 There are nations, like India, that are "sensitive, assertive and proud of their individual personalities.... What is important is that we stand for ourselves. ${ }^{27}$

All of this suggests that there are multiple factors driving domestic weapons production in India, including the weapons-related nuclear and space programs. India's immediate security environment, especially its enduring rivalry with Pakistan and its often hostile relations with China, is perhaps only the most obvious. India's defense programs are also motivated by the hope that they will contribute to industrial development generally. And, most importantly for our purposes, military industrialization has symbolic meaning. It is perceived by Indian elites, and presumably by some nonelites, to enhance India's autonomy in foreign affairs, and ultimately its status and prestige in the international community. It is also seen to enhance the self-confidence of scientific and technical community directly involved in weapons development and production, and the self-image of the entire Indian nation as well. These themes resurface in our analysis of India Today. But first we turn to IR theory.

\section{Symbols and International Relations Theory}

21. Gupta 1981, 243.

22. Sahgal 1978, 40.

23. Tharoor 1982,71 .

24. Aggarwala 1995, 121.

25. Gandhi 1975, 140-141.

26. Tharoor 1982, 88.

27. Jayakar 1992, 255. 
In this section, we highlight the role that symbols and symbolism play in three theoretical frameworks: realism, social constructivism, and the literature on strategic culture. We do this not in order to formulate competing hypotheses anchored to each tradition, but rather to illustrate that the empirical examination of symbols is relevant to a variety of approaches to international relations and thus deserves a more concentrated effort. With such an effort, including some serious attention to issues of measurement, it should be possible to eventually conduct empirical research designed to shed light on disputes between these literatures regarding symbols, their relative importance in motivating state behavior, and their cultural sources.

\section{Realism}

Indigenous arms production is a symbol of Indian power, and thereby enhances its international status and prestige. Such considerations figure prominently in realist theory. E.H. Carr wrote: "Any symptom of military inefficiency or unpreparedness in a Great Power is promptly reflected in its political status"; and "Military power, being an essential element in the life of the state, becomes not only an instrument, but an end in itself." 28 Hans Morgenthau described the symbolism involved in diplomatic ceremonials and displays of military force. "The policy of prestige," he claimed, "is as intrinsic an element of the relations between nations as the desire for prestige is of the relations between individuals." ${ }^{29}$ Neorealists too recognize the importance of prestige on world politics. For Gilpin, one element in the disequilibrium which threatens to lead to hegemonic war is a disjuncture between the international distribution of power and the "hierarchy of prestige." ${ }^{.30}$ On the issue of nuclear weapons in particular, he is troubled by the fact that they "confer an enhanced status and have become status symbols coveted by more and more states." " Krasner's "modified realism," which includes the proposition that third world states are interested in the exercise of "meta-power" via the transformation of international regimes, as opposed to increased wealth, also seems to allow for such things as status and prestige as motivations for state behavior.

Although there is little explicit in the realist literature regarding symbolic motivations behind the pursuit of indigenous arms production capacity, nuclear or non-nuclear, there is nothing in realist theory that is inconsistent with such a characterization of Indian defence industrial policy. But a more serious lapse, something for which realism has been rightly criticized, is the failure to fully examine the source of those motivations (in a sense, preferences) and, more especially, the dynamic relationship between states as actors and the environment within which states interact. ${ }^{32}$ The question neglected by realists is not so much why states pursue the symbols of power in the form of, among other things, military

28. Carr 1939, 110, 111.

29. Morgenthau 1985, 86-87.

30. Gilpin 1981, 14, passim.

31. Ibid., 215-216. On the symbolic and psychological dimensions of nuclear weapons, see especially Jervis 1989, chapter 6.

32. See Wendt 1987. 
industrialization. Waltz, in fact, has a perfectly good generic answer to that question: "The close juxtaposition of states promotes their sameness through the disadvantages that arise from a failure to conform to successful practices.... The socialization of nonconformist states proceeds at a pace that is set by the extent of their involvement in the system." ${ }^{33}$ That is, states, at minimum, want to survive, and a process of social Darwinism tells them that possession of symbols of power will help them to do that. Rather, the more fundamental question neglected by realism is: beyond the utility of symbols for state behavior, what do they say about meaning of statehood itself?

There is in realism a presumption (both analytical and normative) in favor of instrumental state action - variously referred to as "rational," "functional", "outcome oriented," or driven by "material interests." 34 Morgenthau, for example, while recognizing the importance of diplomatic ceremony and military display, was less inclined than Carr to characterize a "policy of prestige" as anything other than an "instrumentality" for the acquisition and maintenance of power: "While in national societies prestige is frequently sought for its own sake, it is rarely the primary objective of foreign policy. Prestige is at most the pleasant by-product of foreign policies whose ultimate objectives are not the reputation for power but the substance of power." 35 In realism, behavior driven purely by symbolic concerns is considered rare. Where behavior is driven by both material interests and symbolic concerns, it is the former that dominate. In contemplating the general notion of rationality, and not necessarily state behavior, Elster has written: "Even though, say, the feeling of gratification or self-realization is essentially a by-product and hence could not be the motivation for action, it could reinforce the motivation to undertake activities of which they are the by-products." ${ }^{36}$ This essentially represents a realist take on arms production in India. International status and prestige, as well as Indian self-confidence, is enhanced by the development of an indigenous arms production capacity. But the central motivation for the development of such capacity is the maximization of India's "material" power (realism) or, at minimum, the survival of the Indian state (neorealism). That status, prestige, and self-confidence also

33. Waltz 1979, 128, also 74-77. Actually, Waltz is referring to the process by which states learn balancing behavior, as opposed to bandwagoning, but socialization presumably explains the learning of other forms of behavior highlighted by realists. For a discussion of the impact on military doctrine, see Posen 1984.

34. It is well to acknowledge that this is a relatively safe position since almost any behavior could be cast in these terms. Useful discussions of the elasticity of such concepts as rationality, interests, and instrumental action in economic discourse can be found in Sen 1977 and Hirschman 1984, 1986. See also the special issue of Political Psychology 16(1), "Political Economy and Political Psychology," especially Monroe 1995 and Simon 1995.

35. Morgenthau 1985, 86, 94. See also Niebuhr 1959, 37-45. It is not quite clear why Morgenthau refers to "reputation for power" here, since reputation would indeed seem to imply the prior exercise of the "substance of power." But his subsequent discussion suggests that the distinction he has in mind is real power and mere symbols of power, the latter resulting from the pursuit of "a policy prestige for its own sake."

36. See Elster 1983, 107; see also 43-108, especially 66-71 on "trying to impress." 
emerge from India's possession of an arms production capacity simply reinforces the more instrumental motivations behind India's policy of military industrialization.

\section{Social Constructivism}

Symbolic motivations for indigenous weapons production, or for any other form of state behavior, may be taken more seriously by social constructivists than by realists. But at its current stage of theoretical evolution, constructivism seems noncommital on questions of relative explanatory importance, which would include questions regarding the relative impact of symbolic versus material forces driving military industrialization. Constructivists, borrowing heavily from the "institutional" approach in sociology, do place special emphasis on the nonmaterial, arguing that "security environments in which states are embedded are in important part cultural and institutional." These environments "affect not only the incentives for different kinds of state behavior but also the basic character of states" - i.e., state identity. ${ }^{37}$ This latter claim sets constructivism apart not only from realism, but also liberalism which, while directing our attention to norms and institutions in international relations, has little to say about the construction of state identity. More important than taking a stand on the neoliberal-neorealist debate about the impact of institutions on state behavior is the constructivist claim that social life, including international life, is "ideas all the way down."38 That is, whether power matters or whether institutions matter, the effects of both operate through their impact on understandings, expectations, and knowledge shared by states. States not only behave (exert power, join institutions) in accordance with cues received from the structure of shared knowledge (or "global culture") of which they are part, they are also defined or constituted by that structure. ${ }^{39}$ Demonstrating the social construction of state identity, as opposed to simply state behavior, represents a major challenge for empirically inclined scholars working within this tradition. It requires distinguishing between, on the one hand, states behaving in ways international society tells them to and, on the other hand, states just being. ${ }^{40}$

These sorts of issues, while important, are not of central concern to us here. The relevance of constructivist theory generally is the prominence given to symbolic motivations for state behavior - or

37. Jepperson, Wendt, and Katzenstein 1996, 33. For recent presentations of the social constructivist position, see also Wendt 1995 and Finnemore 1996, who details its roots in institutionalist sociology.

38. Wendt 1995, 74. Constructivists, at least some, suggest that their approach should ultimately subsume both realism and liberalism in delineating the conditions under which state behavior highlighted by these latter theories operate. See Jepperson et al. 1996, 68-72.

39. Wendt 1987; Giddens 1984.

40. Consider, for example, references by Jepperson at al. 1996, 35-36 to the "character of statehood" as pertaining to state identity, and the degree to which we might be able to distinguish this empirically from state behavior which respects and reinforces existing norms of state sovereignty or practice. 
the symbols of state identity. If state preferences are to be problematized and not taken as given, then constructivism seems more inclined than realism to entertain the possibility that symbolic motivations, and not just material interests, are significant forces behind military industrialization. Suchman and Eyre draw our attention to symbolic motivations in their examination of arms import patterns in the third world. In explaining these patterns, especially very high-end equipment acquisitions which is not obviously the most appropriate from a strictly military (material) viewpoint, they suggest we look to the "metonymical iconography of the global cultural order," which teaches states to covet advanced weaponry not necessarily for its destructive efficiency, but for its "symbolic throw weight." "State preferences are shaped by "an essentially 'ritualistic'... belief in militaries and modern weaponry as distinguishing emblems of the modern nation-state. ${ }^{, 42}$ Military procurement and force structuring exhibit "technologism," or the "symbolic valuation of advanced over alternative technology," which may be less than optimal in the third world context. ${ }^{43}$ The acquisition and, ultimately, the production of advanced weaponry becomes an important feature of state identity. According to Sagan, "military organizations and their weapons can therefore be envisioned as serving fucntions similar to those of flags, airlines, and Olympic teams: they are part of what modern states believe they have to possess to be legitimate, modern states." ${ }^{44}$ This position has been advanced for some time by those working within the "European political economy" tradition. ${ }^{45}$ Kaldor, for instance, maintains that "the possession of weapons systems allows for an ordering of international military relations, conferring political influence, merely through perceptions about military power." Participation in this weapons system thus provides "a form of international legitimacy for Third World governments." 46

The agents of socialization (or acculturation) can be found in the training of third world military elites, first by their colonial authorities and then by both sides in the East-West competition. The process also operates through the international arms trade itself, since "[t]he joint possession of weapons systems and appropriate organisation creates agreement about what constitutes military power." ${ }^{, 47}$ More generally, according to this perspective, states like India adopt preferences for advanced weapons - and, we might add, the capacity to manufacture them — by virtue of being embedded in a particular global culture or "world military order," through which "symbols and meanings prevalent in advanced capitalist societies are imposed on other societies." 48 Empirical researchers have sought to link the movement toward isomorphism in military procurement patterns to the extent of

41. Suchman and Eyre 1992, 149-150, 154.

42. Eyre and Suchman 1996, 92.

43. Wendt and Barnett 1993, 339. Luckham 1984 refers to "fetishism of the weapon," Albrecht and Kaldor 1979 to "technology fetishism." See also Barnett and Wendt 1992 and Wulf 1979.

44. Sagan 1996/97, 74.

45. See Krause 1992, 8.

46. Kaldor 1981, 144.

47. Ibid. See also Mullins 1987, especially chapter 2, and Luckham 1984.

48. Luckham 1984, 32. The notion of a "world military order" is broached by Albrecht and Kaldor 1979 and discussed at greater length in Kaldor 1981. 
immersion in this global culture. Thus, Eyre and Suchman observe a correlation between the possession of symbolically significant weaponry like supersonic aircraft and the state's membership in international governmental organizations. ${ }^{49}$

Rarely, perhaps never, have analysts adopting a sociological perspective taken the position that the forces driving third world arms acquisitions or military industrialization are solely symbolic to the exclusion of more material or functional concerns. (Here is the distinction between weaponry and other more thoroughly symbolic objects like national flags.) The empirical task for social constructivism is therefore rather difficult in this context. It requires not only demonstrating that symbolic concerns do in fact motivate state behavior (and inhere in state identity), but also overcoming a realist bias in security analysis which favors explanations resting upon the material interests of states. If symbolic and material motivations predicted fundamentally different forms of behavior, the task would not be so hard. But both in fact predict advanced weapons acquisition and higher levels of military industrialization. Deriving from the claim that all interests, material ones included, are socially constructed, the position of those doing empirical work within this tradition is that " $[\mathrm{t}]$ he symbolic and the functional values of social objects cannot be simply separated or assessed." We should therefore "begin the study of weapons proliferation with a question, rather than an assumption that one of these two tightly intertwined aspects necessarily dominates." 50

\section{Strategic Culture}

Both neorealism and constructivism would seem to predict convergence among states in regard to their preferences and behavior, as well as their institutions (e.g., militaries). ${ }^{51}$ In realism, state preferences are assumed to be similar at the outset and convergence in state behavior is said to occur through a process of social Darwinism whereby states mimic the successful practices others. In constructivism, the socialization process is more opaque and the analytical emphasis is on formation of state identity and the convergence of institutional forms. State preferences and behavior are affected in

49. Eyre and Suchman 1996. Note that sociologists working with the institutionalist tradition frequently adopt "mainstream" approaches to empirical analysis, including quantitative methods. We offer this as an addendum to Flank's statement that "constructivist analyses often include a textual and interpretive bent" and consist of "thick description, that is, telling stories." See Flank 1993/94, 265; also Lapid 1996 and Yee 1996 on the "third debate" in international relations.

50. Eyre and Suchman 1996, 93 (note 36). See also Sagan 1996/97 and, more generally, Friedland and Alford 1991.

51. Fukuyama 1989, 1992 makes a similar, if more controversial argument, grounded in political philosophy, regarding the triumph and spread of institutions associated specifically with liberal democracy and capitalism. A marxian-inspired approach like world-systems theory would seem to share with realism a skepticism regarding the explanatory power of nonmaterial forces, and at the same time disputes the significance of trends toward isomorphism. See especially Wallerstein 1991. 
the process; they are not exogenous as in realism. ${ }^{52}$ Contrary to both realism and constructivism, the literature on "strategic culture" highlights not convergence, but divergence among states: e.g., in their strategic preferences and doctrines, their military organizational forms, or their very capacity to generate military power. The basic argument here is that domestic society and culture condition the way states perceive and respond to their international environment. States with different social structures and cultures may employ different strategies — by choice or by domestic necessity — to deal with essentially similar international situations and circumstances. One analyst has concluded that external security consideration are secondary in explaining strategic behavior: "Much more important are the non-rational cultural and ideological orientations that shape each nation's level of military preparations." 53

Johnston has usefully characterized the strategic culture literature as consisting of three generations. ${ }^{54}$ The first tended to focus on Soviet and American nuclear doctrine. Explanations for their different approaches to nuclear strategy were fairly deterministic and based on rather timeinvariant conceptions of the superpowers' strategic cultures. The second generation, some contributors to which Johnston locates among the postmodern school of international relations, treats strategic culture as symbolic discourse. The dominant strategic discourse shapes the state's strategic behavior by privileging certain policy options and marginalizing others. But strategic discourse and behavior are also delinked in the sense that, for example, "declaratory strategy" differs from "operational strategy." 55 Since analytical emphasis has been placed on the evolution of strategic discourse, it is not always clear what the implications are for comparative strategic behavior. Tracing the evolution of discourse alongside historical experience suggests, with the rest of the strategic culture literature, that strategic culture varies across states. Still, given the delinkage between declaratory and operational strategy, strategic behavior may not. The third generation, like the second generation, is more nuanced than the first in its conceptions of strategic culture. But unlike postmodern approaches, there is a commitment to assessing whether culture offers a useful explanation for strategic behavior, especially in cases where models based on material interests fall short. ${ }^{56}$

Given the emphasis on symbolic forces, the literature on strategic culture is relevant to our analysis. Borrowing from Clifford Geertz, Johnston has defined strategic cultures as a "system of symbols (e.g., argumentation structures, languages, analogies, metaphors) which acts to establish pervasive and longstanding strategic preferences by formulating concepts of the role and efficacy of military force in interstate political affairs, and by clothing these conceptions with such an aura of factuality that the

52. See, for example, Meyer 1980. Friedland and Alford 1991 discuss the very real distinctions between sociological approach to institutional analysis and the new institutionalism in economics. Their observations apply well to the distinctions between constructivism and neorealism in international relations theory.

53. Payne 1989, 178.

54. Johnston 1995, 36-43.

55. See, for example, Klein 1988, 1989; Shapiro 1990.

56. Examples include Rosen 1996 and Krier 1997. 
strategic preferences seem uniquely realistic and efficacious." ${ }^{.57}$ Symbols are, of course, central in postmodern accounts which, following Jean Baudrillard, contend that "the defense-industrial network produces strategic weapons objects as signs more than real engines of death" and further that "a vital industrial capacity, strong R\&D centers, growing technological capabilities, increasing defense budgets, and constant improvements in the defense-industrial network are a sign-set that must appear in the display of superpower sign-exchange values." ${ }^{, 58}$ Such observations apply to aspiring powers like India as well. Indeed, the advanced weaponry produced by third world states — in effect, copies of the signs themselves - would seem to be a good example of Baudrillard's "simulacra." 59

Contributions to the literature on strategic culture are truly an eclectic set. Most examine in a fairly thorough way the evolution and current forms of particular states' strategic cultures, and thus tend to highlight cross-national differences and the implications for strategic behavior. Positivists among them opt for the standard hypothesis-testing approach, while post-positivists operate in a more interpretive mode or perhaps, more rigorously, trace genealogies. Either approach to strategic culture involves relatively thorough examination of the culture of one or, at the most, a few states: "the writings, debates, thoughts and words of 'culture-bearing units', such as strategists, military leaders and national security elites; weapons designs and deployments; images of war and peace portrayed in various media; military ceremonies; even war literature.' ${ }^{60}$ While there is some recognition that there may be essential ingredients of strategic culture which can be located in many or all nation-states, that concern is secondary, as is any effort to identify the source of any such commonalities. The latter, of course, is the purview of social contructivism, which otherwise shares a great deal both theoretically and substantively with the strategic culture literature.

\section{Weapons Production and Public Discourse in India}

We have suggested that there are a number of factors motivating military industrialization in India. Although realist thought does not deny the existence of symbolic motivations like international status and prestige, or even such things as the state's quest for "self-realization" and "self-confidence," proponents generally downplay the importance of these sorts of motivations relative to material interests. Social constructivists do not at the outset take a stand on the relative importance of material versus nonmaterial interests, or rational versus nonrational behavior. Rather, these are questions for empirical analysis. More importantly, so are questions concerning the (cultural) sources of state interests, material or nonmaterial, and the (social) context of state behavior, rational or nonrational. Postmodern contributions to the literature on strategic culture assert the primacy of symbols and signs, both as cause and consequence of strategic behavior. Other contributions to this literature document these alongside more material elements contributing to a state's strategic culture and, ultimately, to its strategic behavior.

57. Johnston 1995, 46. See also Walker 1986.

58. Luke 1989, 224, 225

59. Baudrillard 1983.

60. Johnston 1995, 49. 
Neither realists nor constructivists have devoted much attention to documenting evidence for the symbolic motivations driving state behavior, especially patterns of weapons acquisition. Realists might be expected to forego the empirical analysis of symbols since they are assumed to play a minor role in the utility functions of states. Postmodern interpretations of strategic culture are often rich with references and examples, but rigorous empirical analysis is not typically of utmost concern given their rejection of positivist epistemology. Social constructivists, while in principle receptive to the documentation of symbolic motivations, have anticipated a bias in the empirical evidence. Suchman and Eyre worry that "locating empirical evidence of nonrational decision making poses a significant methodological problem, particularly for investigators employing case-study techniques. ${ }^{\circ 1}$ Since there is a "rational myth" associated with military strategy and planning itself, an analysis of public justifications for weapons purchases and, by extension, indigenous weapons production "is far more likely to find evidence of strategic, factional, or geopolitical logic than it is to uncover affirmations of ritual conformity." 62 While we acknowledge this potential bias, we are not quite so pessimistic about observing symbolic, nonrational motivations in the public discourse about weapons production. In our review of biographies and memoirs of Indian elites, especially those of Indira Gandhi, we have in fact encountered statements which suggest that military industrialization in India has been driven in part by symbolic as well as material concerns. ${ }^{63}$ Still, a more systematic review of the public discourse in India is necessary in order to demonstrate the viability of this avenue of research. ${ }^{64}$

\section{Methodology}

We assume that India Today, a weekly news magazine comparable to Time or Newsweek in the United States or the Economist in the United Kingdom, is representative of popular discourse on defense policy and foreign affairs. ${ }^{65}$ We reviewed all issues of India Today from 31 May 1977 to 31 December 1996 and identified 126 articles devoted in whole or in part to the issue of indigenous weapons production. Of these, 74 contained one or more statements regarding the motivations for

61. Suchman and Eyre 1992, 151.

62. Ibid. Suchman and Eyre note the applicability of their arguments concerning weapons imports to the issue of weapons production, . See Eyre and Suchman 1996, 100 (note 49).

63. Our previous discussion of the reasons for Indian weapons production includes just a sampling of such statements.

64. One reason for not relying solely on statements of Indian elites, like those found in biographies and memoirs, is that these may be somewhat slanted and even self-serving after the fact. When writing their memoirs, leaders have an incentive to make themselves look good. Even biographers, who may be a little more objective, might report evidence rather selectively in order to highlight a particular psychological profile or quirk. For instance, Tharoor 1982 and Mansingh 1984 frequently explain Indira Gandhi's attitudes and behavior, including behavior on behalf of India, in terms of her personal insecurities.

65. The bi-monthly "international edition” of India Today began being published in May 1989. 
India's domestic arms production programs, including its space and nuclear programs. Such statements in India Today do not necessarily convey official positions or policies of the Indian government. Some are made by government officials, some by military leaders, and some by leading figures in the defense industry. Others represent statements of fact or opinion made by India Today reporters, and these presumably reflect in many instances the views of the magazine's editors. In any event, we are not terribly concerned with examining the official pronouncements justifying Indian military industrialization. In fact, we concur with Suchman and Eyre that official discourse is most likely to be biased by a rationalist myth. ${ }^{66}$ What we want to examine is the popular discourse. Popular discourse, it seems to us, subsumes (non-secret) official discourse, and therefore paints a more complete and a less biased picture of the forces motivating the development of arms production capacity. Reporting in India Today both shapes and is shaped by popular discourse, and is thus an appropriate medium to analyze for our purposes.

Before proceeding to the empirical evidence, we want to be clear about what sort of exercise we are engaging in. First and foremost, this is a descriptive study. We are not analyzing causal mechanisms here. We believe that the motivations behind India's military industrialization, especially symbolic motivations, can be explained in large part by the degree to which India was integrated into the competitive cold war system. This is consistent with both neorealism and social constructivism, but we do not demonstrate the causal relationship empirically. ${ }^{67}$ We also believe that symbolic forces play a larger part in motivating domestic arms production in the third world, including India, than realist theory seems to imply. But, again, we do not examine empirically the relative importance of symbolic versus material motivating forces. What we do show is that the symbolic motivations behind Indian weapons programs find expression in the public discourse, and that they appear regularly enough to suggest that they are significant factors driving these programs. And we suspect that they are more than mere by-products of the pursuit of material interests. We want to suggest that statements regarding the symbolic importance of an Indian arms production capacity reflect regular and consistent motivating forces - that they do not reflect mere idiosyncracies of time or space. In other words, they are not "outliers." This is the primary "descriptive inference" we draw from our systematic review of India Today. ${ }^{68}$

\section{Empirical Evidence}

Although we were able to document several types of motivations for Indian arms production, our aim in this paper is to present a variety of statements which represent symbolic motivations. We can, however, give some indication of the relative frequency with which the various types of motivations,

66. See Shapiro 1992 for an analysis of the construction of the "official" discourse of security policy and strategies for legitimating it through popular media, in this case films and video.

67. For one very preliminary attempt to do so for five leading third world arms producers, including India, see [author].

68. For a methodological guide to descriptive inference, see King et al. 1994, 35-74. 
material and symbolic, appear in the public discourse. Of the 74 articles in which justifications for indigenous weapons programs are mentioned, 56 mention India's enduring conflicts with Pakistan and/or China, or regional security somewhat more generally. Of the 74, eighteen mention India's dependence on foreign suppliers of complete weapons systems or spare parts, with negative implications for India's warfighting capabilities. Twenty-six address economic issues such as promoting the development of civilian industries, saving foreign exchange, or obtaining technology transfers. Lastly, 24 articles make reference to what we consider to be more symbolic concerns. These in turn fall into three categories: India's autonomy in foreign affairs, India's international status and prestige, and India's self-image.

\section{Exhibit A: On Indian Autonomy}

Rather than flatly categorizing military hardware or defense industrial policy as either of symbolic or functional import, it is probably better to appreciate that some mix of the two often obtains. This mix is apparent in statements which link Indian accomplishments in weapons development to an increase in Indian autonomy.

[1] 'This approach of 'capability matching' rather than building strength to suit the nation's long-term threat wastes money and gives India's defence doctrine an undesirable defensive hue. Besides such armament decisions also make the country increasingly dependent on foreign sources. Says [defense analyst] Jaswant Singh: 'You always pay a political price for arms imports. Weapon supply is after all a lubricant of diplomacy today.",69

[2] "Though the speech played down Agni's strategic importance, Rajiv personally added a line: 'We must remember that technological backwardness also leads to subjugation.",70

There is an explicit recognition on the part of Indian elites that the failure to produce advanced weaponry threaten to limit India's maneuverability in the exercise of foreign policy, but only in the vaguest terms. $^{71}$ Rajiv Gandhi's reference to "subjugation" is intended to highlight the dangers of becoming dependent on the superpowers in particular (excerpt [2]), as are other statements reported in India Today:

[3] "... The MiG-29 purchase also symbolises the return to an era of dependency, since it is just one item in an overflowing basket of weaponry that India has been buying from Moscow in the last two years, ranging from tanks to high reconnaissance spy planes to missiles and helicopters.... What is causing even greater concern is the fact that dependence on the Soviets is now

69. Shekar Gupta, "The New Thrust," India Today, 15 November 1985.

70. Dilip Bobb, "Chariot of Fire," India Today, 15 June 1989.

71. All italics are ours. 
creeping into new areas that undermine India's laborious attempts to become self-reliant in defence production." ${ }^{, 72}$

[4] "India, it would seem, has no alternative but to maintain a modern, mobile and efficient military machine. How this can be done in a realistic manner, without squandering national foreign exchange reserves and becoming dependent on either or both of the superpowers is a question that will increasingly bother India's defence planners in the years to come."73

Aside from India's more material interest in not squandering foreign exchange reserves, here again the concern seems to be with dependence per se, not the implications for India's overall military capacity which is presumably enhanced by such dependence. Clearly, short-term military capacity is not all that matters to Indian defense planners given their "laborious attempts" to indigenize defense production (excerpt [3]).

Indigenization has indeed taken on symbolic significance in India, to the point of becoming an emblem of Indian nationalism:

[5] 'Indian military aircraft designers have sat virtually idle for nearly 20 years since HAL's HF-24 project folded up. 'The aeronautical community has been treated brutally for 25 years. We have lost two generations of aeronautical engineers. That's why we are now on a swadeshi track' explains Arunachalam [scientific advisor to the defence minister]. And the LCA team leader Harinarayana aptly symbolises this swadeshi spirit. 'I am a totally indigenous product,' he proclaims proudly. 'I have never studied or worked abroad.",74

[6] On Pakistan's nuclear potential: "Political analyst Hari Jaisingh says: '... The BJP's stand is crystal clear. It wants a swadeshi bomb.","75

[7] "Each Arjun will cost Rs 7.5 crore to Rs 11 crore each, which ironically is close to the price of an imported tank. But then indigenisation is the raison d'etre of the MBT project."

The term "swadeshi" was popularized by Mahatma Gandhi in the context of his campaign to encourage Indians to spin their own cloth instead of relying on British imports, and thus the term has considerable nationalistic overtones. It is not surprising therefore that the intensely nationalistic Bharatiya Janata Party would call for a "swadeshi bomb" (excerpt [6]). The notion is taken to a slightly comical extreme

72. Dilip Bobb, “Moscow's New Offensive," India Today, 31 August 1984.

73. Shekar Gupta, "The New Thrust," India Today, 15 November 1985.

74. Ramindar Singh, “Trouble Before Take-off," India Today, 31 January 1986.

75. Dilip Bobb and Ramindar Singh, "Pakistan's Nuclear Bombshell," India Today, 31 March 1987.

76. Kanwar Sandhu, “On Course, Finally,” India Today, 15 July 1993. 
when the LCA team leader uses swadeshi to describe himself (excerpt [5]). The symbolism inherent in indigenization is amply demonstrated by the observation that, although the Arjun tank is no less expensive than an import, to dwell on such material issues misses the point of indigenization (excerpt [7]).

The symbolic significance of military industrialization is also illustrated by a desire not merely to establish and protect Indian autonomy, but also to demonstrate Indian accomplishments to the rest of the world, or at least to those states that might be impressed:

[8] General B.C. Joshi, chief of army staff: "And because [Prithvi] is indigenously produced, it is far more important. Self-sufficiency is critical in this area. Now we are not beholden to any foreign power.... Agni has tremendous potential as it puts you in a totally different league. And as a technology demonstrator, the missile's success is of great significance to the country.",77

[9] "For years, the US had banned the sale of technology and material that could contribute to India's space and missile programme. While this helped delay its development, India demonstrated that it could successfully indigenise sophisticated technology."

[10] On the airborne surveillance platform: "So, could the purpose of flying the patently incomplete ASP be to show that we can 'thump' the Pakistanis, given the fact that Pakistan can lease the US-made system from Saudi Arabia in a time of crisis? Or is it simply a message to [airborne early warning]-manufacturing nations, saying: 'If you don't sell it to us, we'll make it ourselves.",79

These statements suggest that it is important both to develop advanced weapons technology and to make the international community aware that it has been developed. Of the various types of statements which link military industrialization to the promotion and protection of Indian autonomy, these are perhaps most indicative of the importance of symbolism. Quite aside from whether India actually exercises its autonomy in foreign affairs, it is vitally important that the signs of Indian autonomy be "demonstrated" to the rest of the world (excerpts [8] and [9]). Indigenous weaponry, even when incomplete, sends "a message" to other arms producing states content to withhold their advanced technology from the international arms market (excerpt [10]).

77. Raj Chengappa, "The Missile Man,” India Today, 15 April 1994.

78. Raj Chengappa, "Nuclear Blackmail," [title?] India Today, 30 April 1994.

79. Avirook Sen, "Ground Realities," India Today, 31 December 1996. 


\section{Exhibit B: On India's International Status and Prestige}

The purposes behind India's quest for autonomy in military production are both functional and symbolic, and we have tried to identify statements which reflect on the latter dimension. The reference above to Agni's potential for placing India in a "totally different league" (excerpt [8]) is echoed in other statements which reflect more explicitly India's international aspirations:

[11] "The success of the SLV-3-(E)-02, a completely indigenous four-stage rocket... put India into an exclusive club with only five other members.... 'This is a great day for India and Indian science,' proclaimed Mrs Gandhi echoing the popular view.... ${ }^{980}$

[12] "Whether in the corridors of the Defence R\&D department in Delhi, or in the Bangalore offices of the Aeronautical Development Agency (ADA), the apex body which overseas the design and development of the LCA, there is an infectious enthusiasm that the LCA prototype will fly by 1989 and that it will catapult India into the technological superleague of nations who produce their own frontline fighter planes.

[13] "At exactly 7:17 a.m. on May 22, Agni blossomed into a chariot of fire that propelled India into an exclusive club dominated by the world's technological and military giants." ${ }^{, 82}$

[14] On the unsuccessful test of the Polar Satellite Launch Vehicle: “...PSLV's success would have made India a major player in the commercial space arena. As Professor Rao [chairman of the Space Research Organisation] says: 'It is a quantum leap in space technology for us and it would have given us the muscle power to put anything into space.' What was left unstated was that if PSLV succeeded, India could have also muscled into the exclusive club of countries having Inter-Continental Ballistic Missile (ICBM) capability. ${ }^{193}$

[15] "Recently, a series of developments have powered the nation into the rarefied strata of strategic missile competence. Topping the list is the successful third launch of Agni, India Intermediate range Ballistic Missile (IRBM), on February 19. ${ }^{94}$

All of these excerpts contain references to an elite group of nations that possess the capacity to produce one or another category of military hardware - the "superleague of nations" producing fighters (excerpt [12]), the "exclusive club" or "rarefied strata" producing longer-range missiles

80. Suman Dubey, "Soaring Into the Space Age," India Today, 15 August 1980.

81. Ramindar Singh, "Trouble Before take-off," India Today, 31 January 1986.

82. Dilip Bobb, "Chariot of Fire," India Today, 15 June 1989.

83. Raj Changappa, "PSLV's Deviant Behaviour," India Today, 15 October 1993.

84. Raj Chengappa, “The Missile Man,” India Today, 15 April 1994. 
(excerpts [11], [13-15]) — as well as India's acquisition or impending acquisition of elite status. Other statements recognize that certain capabilities are necessary symbols of international status and prestige:

[16] Interview with Air Chief Marshal Denis A. La Fontaine: "If we do not indigenise, how will we become a first class nation?" 85

[17] "While the haggling goes on, the desperate need for the jet trainers is a grim reminder of the reality that the Indian policy makers seem to ignore in their heady rush for 'mini-power status': that no nation has ever become a real power with its army firing mostly imported guns, its air force flying foreign aircraft and its navy riding submarines leased from another superpower.

[18] A.P.J. Abdul Kalam, head of the defence research program: “... India can now be rated as a missile power that can deliver a range of missiles any time, anywhere that we want. Agni symbolises our technological capabilities. Prithvi is a world class surface-to-surface missile. In the anti-tank class we want to be number one with Nag. Akash is heading for a unique second in its surface-to-air class.

[19] "Says Muchkund Dubey [former foreign secretary]: 'The bomb option is a currency of power that is critical to our survival as a strong nation." $" 88$

Here is the assertion that if India wants to become a "first class nation," or even if India aspires to "mini-power status," it cannot rely on imported weaponry because "real power" requires something more (excerpts [16] and [17]). Again, it is indigenous arms production, especially production of "world class" missiles like Agni and Prithvi, which will "symbolise" India's technological capabilities (excerpt [18]). The option to use nuclear weapons, now that India has developed its own missile capacity, can be used as a "currency of power" (excerpt [19]). Such are the elements of international status and prestige identified in Indian discourse.

\section{Exhibit C: On India's Self-image}

We have noted that the writings and speeches of Indira Gandhi sometimes betray a certain concern about India's collective inferiority complex, especially the lack of pride among Indian scientists and engineers. They also express hope that military industrialization might play a role in enhancing Indian identity. Statements found in India Today suggest that Gandhi was not alone in either her concerns or her solutions :

85. Shekar Gupta, "Design Gap,” India Today, 15 November 1985.

86. Shekar Gupta, “A Sea Change,” India Today, 31 December 1987.

87. Raj Chengappa, “The Missile Man,” India Today, 15 April 1994.

88. Raj Chengappa, "Nuclear Blackmail," [title?] India Today, 30 April 1994. 
[20] On the launch of the SLV-3: "'With the team I have,' said U.R. Rao who heads the Indian Space Research Organization's Satellite Centre (Isac) near Bangalore, 'I have enough confidence to build anything let alone satellites." 89

[21] "Says Dr A.P.J.A. Kalam, chief architect of Agni and the brain behind the success of the [Integrated Guided Missile Development Programme]: 'Agni gives us the confidence that we are capable of producing any kind of missile. We are now self-sufficient both in design and missile technology." $" 90$

That individuals in such high positions in India's space technology community would speak of such successes in terms of enhanced "confidence" reveals something about their prior lack of it.

Demonstrations of Indian technological prowess not only contribute to the country's international status and prestige; they also provide a needed boost to India's image of itself. Other statements employ telling metaphors:

[22] "Says a top-level defence scientist: 'Prithvi could be a really major achievement. It signals our coming of age." 91

[23] On the LCA project: "Ever since the HF 24's partial success, negated largely by the lack of a good engine, the IAF has depended on licensed production or off-the-shelf purchases. The Jaguar, the Mirage 2000 and the MiG 29 have given the IAF plenty of punch but it has not led to any major transfer of technologies. Now, as a defence expert says: 'We are toddlers in the business. We are groping for help." 92

[24] A.P.J. Abdul Kalam, head of the defence research program: "Let us imagine a situation where we don't have strategic missiles and nations around us have either developed or purchased them. We would then be dependent on another country to help us out. Today our missile programme is playing a role in helping us stand on our legs." 93

Various stages of physical development are alluded to here — standing, toddling, coming of age — but all of them suggest a degree of immaturity relative to other nation-states that India aspires to emulate. Such references, along with those applauding increased self-confidence (excerpts [20] and [21]) do seem infused with more humility than statements asserting Indian autonomy or its international status and prestige. The symbolism is no less significant, however. India is like a child maturing into adulthood.

89. Suman Dubey, "Soaring Into the Space Age," India Today, 15 August 1980.

90. Dilip Bobb, "Chariot of Fire," India Today, 15 June 1989.

91. Shekar Gupta, "Shooting Ahead," India Today, 31 March 1988.

92. Raj Chengappa, “A Testing Time,” India Today, 31 August 1988.

93. Raj Chengappa, “The Missile Man,” India Today, 15 April 1994. 
The process of military industrialization may be slow, but it is perfectly natural, indeed inevitable, for a country like India who wants to grow up to be a major power someday.

\section{Conclusion}

In December 1995, India Today polled residents in nine major Indian cities on matters of nuclear policy. Sixty-two percent approved of nuclear testing for purposes of developing India's nuclear weapons capability. Of these, 95 percent felt that the nuclear option was important in order to protect India against nuclear threats from China and Pakistan, and 85 percent felt that it was important to improve India's international bargaining power generally. These, of course, are functional concerns. But 83 percent also gave another reason for India's nuclear capability: "enhancing our international status." ${ }^{, 94}$ Indians recognized the symbolic import of nuclear weapons, and distinguished this from more functional motivations.

We reach a similar conclusion. Our analysis of India Today, India's leading news magazine, suggests that India's material interests provide a central impetus for the policy of military industrialization. They may well be paramount. Most references to India's weapons production cite the country's enduring tensions with Pakistan and China. Many other statements refer to the enhancement of India's warfighting capacity in more general terms, especially the dangers involved in remaining dependent on foreigners for weapons and spare parts during wartime. Economic issues are frequently mentioned as well, including the beneficial effects of military industrialization on the development of civilian industries, and the foreign exchange to be saved with import substitution. It is abundantly clear to us that many Indians perceive that the state's material interests are served by the development of an indigenous defense industry. At the same time, however, many of the other benefits accruing from military industrialization appear to be primarily symbolic.

There are three closely interrelated yet distinguishable concerns in the public discourse which we consider symbolic. The first is that military industrialization is a means of asserting India's autonomy in international affairs. Guarding one's autonomy is, to be sure, standard fare among sovereign states, and more so among third world states, or "quasi-states," which otherwise lack the institutional capacity to both promote and protect the welfare of their citizenry. ${ }^{95}$ India probably does not fall into this latter category, but autonomy has nonetheless become emblematic of Indian statehood in the public discourse. The symbolic dimension is well captured by references to the "swadeshi" spirit among defense industry personnel, and to "swadeshi" bombs. Now autonomy in weapons production is certainly of great functional value, especially to protect against leverage that might otherwise be exercised by arms suppliers, but we have also found that references of this sort are relatively easy to separate from references to Indian autonomy as a symbol of Indian statehood.

94. “Opinion Poll: Yes to the Bomb," India Today, 31 December 1995.

95. On quasi-states and the distinction between juridical and empirical statehood, see Jackson 1990. 
A second concern evident in the public discourse is India's international status and prestige. There is an apparent preoccupation with what it takes to become a member of the "superleague," "rarefied strata," or "exclusive club" of nation-states. Whether India has achieved that ranking or, if not, what still remains to be accomplished in the area of defense industrialization is the subject of some debate. That India is destined for such greatness is generally taken for granted. Moreover, prestige is not sought for particular instrumental purposes. Short-term goals do not attach to statements regarding India's international status, current or immanent, nor do the sorts of longer-term messianic goals we might expect from a leading state in the nonaligned movement. There is no doubt an understanding that international status and prestige will afford India a degree of influence over the international rules of the game, and thus a recognition that military industrialization may allow India to exercise structural or hegemonic power (or to check it), but such intentions do not find much expression in the public discourse. ${ }^{96}$ As a symbol of Indian statehood, international prestige looks to be primarily an end in itself.

India's self-image is the third symbolic theme we identify in the public discourse. Of course, technically, references to India's autonomy and to its international status and prestige are also part of India's self-image, but there is something unique about the sorts of statements we group in this third category. There is, shall we say, less posturing involved and more self-reflection. References to India as "toddler" or as "coming of age," as well as to enhanced self-confidence, suggest that India still has a ways to go before entering "adulthood" - i.e., membership in the superleague or rarefied strata of nations. Such sentiments surely reflect more humility on the part of particular participants in the public discourse, but they also stand out as echoing a key dimension of Indian identity discernible in some of Indira Gandhi's public statements and reminiscences. Whether they reflect "true" Indian identity or whether Gandhi's was projecting some of her own psychological insecurities onto the nation as a whole, as some of her biographers have suggested, is not an issue we are presently able to address. It will suffice to say that there is in Indian public discourse a linkage between military industrialization and maturity and self-confidence, desired symbols of Indian statehood. ${ }^{97}$

What have we accomplished in our analysis of India Today? First, despite the rational myth which may well surround military procurement and planning in India, indigenously produced weaponry clearly does have symbolic throw weight, and this is evident in Indian public discourse. Second, we contend that symbolic motivations represent a systematic component of the military industrialization process in India. ${ }^{98}$ The precise form that symbolic motivations take vary - some statements seem to have more symbolic content than others - but as a whole, such references are not rare or isolated; they are not "outliers." We are confident in this judgment because we have subjected India Today to a rigorous examination, not a selective one, and have documented (though not reported) all sorts of expressed motivations for military industrialization, not just symbolic ones. As an "estimator," India Today may

96. See Krause 1991 on the different types of power — bargaining, structural, and hegemonic — potentially exercised by arms suppliers.

97. Mansingh 1984 and Tharoor 1982 are examples.

98. Here we are taking cues from King et al. 1994, 55-74. 
be biased, as our particular reading of it may be, but these issues can be addressed by attempting replication (e.g., analysis of other sources). ${ }^{99}$ In fact, following Suchman and Eyre, it is not unreasonable to expect that symbolic motivations are under represented in the public discourse, including such vehicles as India Today, given the rational myth attending military and security issues. ${ }^{100}$ The nature of the most probable bias, then, gives us an extra degree of confidence that the process generating these data is real (which is not to say, material).

Ultimately, we would like to go beyond descriptive inference. Assessing the relative importance of the symbolic motivations driving military industrialization in India, especially as compared to material or instrumental motivations, is critical if we are to deepen our understanding of the process. It might also reflect on at least some of the competing claims found in the theoretical literature, since the mere presence of symbols and symbolic concerns is really not in dispute. However, both the realist and social constructivist literatures, as well as the eclectic literature on strategic culture, are relatively underdeveloped on such matters. It is difficult to imagine what it would take by way of empirical testing to settle any disagreements between them. From realism, we expect some skepticism regarding the importance of nonmaterial interests in driving military industrialization. From postmodern contributions to the strategic culture literature, we do not expect such skepticism. In fact, the claim is that symbols, or signs, are what states ultimately value, not the material objects or qualities they signify. Nor from constructivism do we expect skepticism, but at the same time we expect less attention devoted to impact of symbols than to the international social context which conditions the valuing of certain objects and qualities as symbols. Empirical investigation is appropriate for all three approaches (despite some fairly serious epistemological disputes) and might just prompt greater theoretical specificity and refinement.

Fukuyama has commented that Hegel's "first man" can be distinguished from other species in that "he desires not only real, 'positive' objects — a steak, or fur jacket with which to keep warm, or a shelter in which to live — but also objects that are totally non-material. Above all, he desires the desire of other men, that is, to be wanted by others or to be recognized." India, and many other states, may be like Hegel's first man whose "own sense of self-worth and identity is intimately connected with the value that other people place on him." 101 It could be that the preoccupation with symbols of statehood is most pronounced for relatively recent entrants into the society of states. That is an empirical question, and, by focusing on forms of state behavior like indigenous weapons production, it is plainly a researchable one.

99. We are in fact engaged in one such effort using the Times of India and the Illustrated Weekly of India.

100. Suchman and Eyre 1992.

101. Fukuyama 1992, 146-147. 


\section{References}

Aggarwala, Adish C. 1995. Prime Minister Narasimha Rao: Scholar Prime Minister. New Delhi: Amish.

Albrecht, Ulrich and Mary Kaldor. 1979. Introduction. In The World Military Order: The Impact of Military Technology on the Third World, edited by Maty Kaldor and Asbjørn Eide. New York: Praeger.

Ball, Nicole. 1988. Security and Economy in the Third World. Princeton: Princeton University Press. Barnds, William J. 1972. India, Pakistan, and the Great Powers. New York: Praeger.

Barnett, Michael and Alexander Wendt. 1992. The systemic sources of dependent militarization. In The Insecurity Dilemma: National Security of Third World States, edited by Brian L. Job. Boulder, CO: Lynne Rienner.

Baudrillard, Jean. 1983. Simulations. New York: Semiotext(e).

Benoit, Emile. 1973. Defense and Growth in Developing Countries. Lexington, MA: Lexington Books.

Brands, H.W. 1990. India and the United States: The Cold Peace. Boston: Twayne.

Carr, E.H. 1946. The Twenty Years' Crisis, 1919-1939: An Introduction to the Study of International Relations. New York: Harper and Row.

Conca, Ken. 1992. Third world military industrialization and the evolving security system. In The Highest Stakes: The Economic Foundations of the Next Security System, by Wayne Sandholtz et al. New York: Oxford University Press.

Elster, Jon. 1983. Sour Grapes: Studies in the Subversion of Rationality. Cambridge: Cambridge University Press.

Eyre, Dana P. and Mark C. Suchman. 1996. Status, norms, and the proliferation of conventional weapons: An institutional theory approach. In The Culture of National Security: Norms and Identity in World Politics, edited by Peter J. Katzenstein. New York: Columbia University Press.

Finnemore, Martha. 1996. Norms, culture, and world politics: Insights from sociology's institutionalism. International Organization 50(2): 325-347.

Flank, Steven. 1993/94. Exploding the black box: The historical sociology of nuclear proliferation. Security Studies 3(2): 259-294.

Friedland, Roger and Robert R. Alford. 1991. Bringing society back in: Symbols, practices, and institutional contradictions. In The New Institutionalism in Organizational Analysis, edited by Walter W. Powell and Paul J. DiMaggio. Chicago: University of Chicago Press.

Fukuyama, Francis. 1989. The end of history? The National Interest 16: 3-18.

Fukuyama, Francis. 1992. The End of History and the Last Man. New York: Free Press.

Gandhi, Indira. 1975. India: The Speeches and Reminiscences of Indira Gandhi, Prime Minister of India. Calcutta: Rupa and Company.

Giddens, Anthony. 1984. The Constitution of Society: Outline of the Theory of Structuration. Cambridge: Polity Press.

Gilpin, Robert. 1981. War and Change in World Politics. Cambridge: Cambridge University Press. 
Graham, Thomas. 1984. India. In Arms Production in Developing Countries, edited by James Everett Katz. Lexington, MA: Lexington Books.

Gupta, Sisir. 1981. India and the International System, edited by M.S. Rajan and Shivaji Ganguly. New Delhi: Vikas.

Hegel, G.W.F. 1971. The Phenomenology of Mind. Translated by R.S. Hartman. London: George Allen \& Unwin.

Hirschman, Albert O. 1984. Against parsimony: Three easy ways of complicating some categories of economic discourse. American Economic Review 74: 89-96.

Hirschman, Albert O. 1986. Rival Views of Market Society and Other Recent Essays. Cambridge: Harvard University Press.

Hoyt, Timothy D. 1996. Rising Regional Powers: New Perspectives on Indigenous Defense Industries and Military Capability in the Developing World. Ph.D. dissertation, Johns Hopkins University.

Jackson, Robert H. 1990. Quasi-states: Sovereignty, International Relations and the Third World. Cambridge: Cambridge University Press.

Jayakar, Pupul. 1992. Indira Gandhi: An Intimate Biography. New York: Pantheon.

Jepperson, Ronald L., Alexander Wendt, and Peter J. Katzenstein. 1996. Norms, identity, and culture in national security. In The Culture of National Security: Norms and Identity in World Politics, edited by Peter J. Katzenstein. New York: Columbia University Press.

Jervis, Robert. 1989. The Meaning of the Nuclear Revolution: Statecraft and the Prospect of Armageddon. Ithaca, NY: Cornell University Press.

Johnston, Alastair Iain. 1995. Thinking about strategic culture. International Security 19(4): 32-64.

Katz, James Everett. 1984. Understanding arms production in developing countries. In Arms Production in Developing Countries: An Analysis of Decision Making, edited by James Everett Katz. Lexington, MA: Lexington Books.

Kennedy, Gavin. 1974. The Military in the Third World. New York: Charles Scribner's Sons.

King, Gary, Robert O. Keohane, and Sidney Verba. 1994. Designing Social Inquiry: Scientific Inference in Qualitative Research. Princeton: Princeton University Press.

Klein, Bradley S. 1988. Hegemony and strategic culture: American power projection and alliance defence politics. Review of International Studies 14(2): 133-148.

Klein, Bradley S. 1989. The textual strategies of the military: Or have you read any good defense manuals lately? In International/Intertextual Relations: Postmodern Readings of World Politics, edited by James Der Derian and Michael J. Shapiro. Lexington, MA: Lexington Books.

Kolodziej, Edward A. 1985. National security and modernization: Drive wheels of militarization. In Third World Militarization: A Challenge to Third World Diplomacy, edited by Jagat S. Mehta. Austin, TX: Lyndon B. Johnson School of Public Affairs.

Krasner, Stephen D. Structural Conflict: The Third World Against Global Liberalism. Berkeley: University of California Press.

Krause, Keith. 1991. Military statecraft: Power and influence in Soviet and American arms transfer relationships. International Studies Quarterly 35(3): 313-336.

Krause, Keith. 1992. Arms and the State: Patterns of Military Production and Trade. Cambridge: Cambridge University Press. 
Krier, Elizabeth. 1997. Imagining War: French and British Military Doctrine Between the Wars. Princeton, NJ: Princeton University Press.

Lapid, Yosef. 1996. Culture's ship: Returns and departures in international relations theory. In The Return of Culture and Identity in IR Theory, edited by Yosef Lapid and Friedrich Kratochwil. Boulder, CO: Lynne Rienner.

Luckham, Robin. 1984. Armament culture. Alternatives 10(1): 1-44.

Luke, Timothy. 1989. "What's wrong with deterrence?" A semiotic interpretation of national security policy. In International/Intertextual Relations: Postmodern Readings of World Politics, edited by James Der Derian and Michael J. Shapiro. Lexington, MA: Lexington Books.

Mansingh, Surjit. 1984. India's Search for Power; Indira Gandhi's Foreign Policy, 1966-1982. New Delhi: Sage.

Meyer, John W. 1980. The world polity and the authority of the nation-state. In Studies of the Modern World-System, edited by Albert Bergesen. New York: Academic Press.

Morgenthau, Hans J. 1985. Politics Among Nations: The Struggle for Power and Peace, sixth edition revised by Kenneth W. Thompson. New York: Alfred A. Knopf.

Mullins, A.F., Jr. 1987. Born Arming: Development and Military Power in New States. Stanford: Stanford University Press.

Niebuhr, Reinhold. 1959. The Structure of Power. New York: Scribner's Sons.

Nolan, Janne E. 1991. Trappings of Power: Ballistic Missiles in the Third World. Washington, DC: Brookings Institution.

Office of Technology Assessment, U.S. Congress. 1991. Global Arms Trade: Commerce in Advanced Military Technology and Weapons. Washington: U.S. Government Printing Office.

Payne, James L. 1989. Why Nations Arm. New York: Basil Blackwell.

Posen, Barry. 1984. The Sources of Military Doctrine: France, Britain, and Germany between the World Wars. Ithaca, NY: Cornell University Press.

Rao, V.K.R.V. 1984. The Current Indian Crisis: Darkness Before Dawn. Allahabad: Vohra. Renwick, Kristen with Kristen Hill Maher. 1995. Psychology and rational actor theory. Political Psychology 16(1): 1-21.

Rosen, Stephen Peter. 1996. Societies and Military Power: India and Its Armies. Ithaca, NY: Cornell University Press.

Sagan, Scott D. 1996/97. Why do states build nuclear weapons? Three models in search of a bomb. International Security 21(3): 54-86.

Sahgal, Nayantara Pandit. 1978. Indira Gandhi's Emergence and Style. New Delhi: Vikas.

Sanders, Ralph. 1990. Arms Industries: New Suppliers and Regional Security. Washington: National Defense University Press.

Sen, Amartya. 1977. Rational fools: A critique of the behavioral foundations of economic theory. Philosophy and Public Affairs 6: 317-344.

Shapiro, Michael J. 1990. Strategic discourse/discursive strategy: The representation of "security policy" in the video age. International Studies Quarterly 34(3): 327-340.

Simon, Herbert A. 1995. Rationality and political behavior. Political Psychology 16(1): 45-61. 
Smith, Chris. 1994. India's Ad Hoc Arsenal: Direction or Drift in Defence Policy? New York: Oxford University Press.

Suchman, Mark C. and Dana P. Eyre. 1992. Military procurement as rational myth: Notes on the social construction of weapons proliferation. Sociological Forum 7(1): 137-161.

Thakur, Ramesh. 1994. The Politics and Economics of India's Foreign Policy. New York: St. Martins.

Tharoor, Shashi. 1982. Reasons of State: Political Development and India's Foreign Policy under Indira Gandhi, 1966-1977. New Delhi: Vikas Publishing.

Thomas, Raju G.C. 1986. Indian Security Policy. Princeton: Princeton University Press.

Walker, R.B.J. 1986. Culture, discourse, insecurity. Alternatives 11(4): 485-504.

Wallerstein, Immanuel. 1991. The national and the universal: Can there be such a thing as world culture? In Culture, Globalization and the World-System, edited by A.D. King. London: Macmillan.

Waltz, Kenneth. 1979. Theory of International Politcs. Reading, MA: Addison-Wesley.

Wendt, Alexander. 1987. The agent-structure problem in international relations theory. International Organization 41(3): 335-370.

Wendt, Alexander. 1995. Constructing international politics. International Security 20(1): 71-81.

Wendt, Alexander and Michael Barnett. 1993. Dependent state formation and third world militarization. Review of International Studies 19: 321-347.

Wulf, Herbert. 1979. Dependent militarism in the periphery and possible alternative concepts. In Arms Transfers in the Modern World, edited by Stephanie G. Neuman and Robert E. Harkavy. New York: Praeger.

Wulf, Herbert. 1986. India: The unfulfilled quest for self-sufficiency. In Arms Production in the Third World, edited by Michael Brzoska and Thomas Ohlson. London: Taylor and Francis.

Yee, Albert S. 1996. The causal effect of ideas on policy. International Organization 50(1): 69-108. 